\title{
PENGARUH PEMBELAJARAN BERBASIS MASALAH DIPADUKAN LKPD 5E TERHADAP KETERAMPILAN PROSES SAINS PESERTA DIDIK
}

\section{THE EFFECT OF PROBLEM BASED LEARNING MODEL COMBINED WITH THE STUDENT ACTIVITY SHEET (LKPD) BASED 5E ON THE STUDENT SCIENCE PROCESS SKILLS}

\author{
Hidayatussakinah $^{1}$, Jamaluddin $^{2 *}$, Dadi Setiad $^{2}$ \\ 1 Mahasiswa Program Magister Pendidikan IPA, Universitas Mataram, Indonesia \\ 2 Dosen Program Studi Magister Pendidikan IPA, Universitas Mataram, Indonesia \\ *Email: hidasz180118@gmail.com
}

Diterima: 8 Julli 2019. Disetujui: 9 Juli 2019. Dipublikasikan: 31 Juli 2019

\begin{abstract}
Abstrak: Pembelajaran berbasis masalah dipadukan LKPD 5E merupakan inovasi pembelajaran yang berfokus pada peserta didik (student center). Tujuan penelitian adalah untuk mengetahui pengaruh dan interaksi pembelajaran berbasis masalah dipadukan LKPD 5E dengan kemampuan akademik terhadap keterampilan proses sains peserta didik. Jenis penelitian ini adalah eksperimen semu dengan desain penelitain non equivalent pretestposttest control group design. Populasi penelitian adalah semua peserta didik kelas VII SMP Negeri 3 Mataram berjumlah 262 orang. Sampel penelitian terdiri dari empat kelas berjumlah 114 orang, diambil dengamenggunakan teknik sampling purposive. Instrumen yang digunakan untuk mengukur keterampilan proses sains adalah lembar observasi keterlaksanaan RPP dan tes uraian. Data dianalisis menggunakan uji Anakova. Hasil penelitian menunjukkan bahwa: (1) Model pembelajaran berbasis masalah dipadukan LKPD 5E berpengaruh secara signifikan terhadap keterampilan proses sains peserta didik; (2) Kemampuan akademik berpengaruh terhadap keterampilan proses sains peserta didik; (3) Ada interaksi antara model pembelajaran berbasis masalah dipadukan LKPD 5E dengan kemampuan akademik terhadap keterampilan proses sains.
\end{abstract}

Kata Kunci: Model Pembelajaran Berbasis Masalah (PBM), Lembar Kegiatan Peserta Didik (LKPD) 5E dan Keterampilan Proses Sains.

\begin{abstract}
Problem Based learning combined with LKPD 5E is a learning innovation that focuses on students (student center). The aim of the study was to determine the effect and interaction of problem based learning combined with LKPD 5E with academic ability on students' science process skills. The research type is a quasi experiment with a non equivalent pretest posttest control group design. The study population was all students of grade seven of SMP Negeri 3 Mataram, in total 262 students. The studied samples consisted of four classes, in total 114 sudents. The sample was taken by purposive sampling techniques. The instrument used to measure science process skills is the lesson plan observation and description test. Data were analyzed using the Anakova test. The results showed that: (1) Problem based learning models combined with LKPD 5E had a significant effect on students' science process skills; (2) Academic abilities affect students' science process skills; (3) The interaction between the problem based learning model combined with LKPD 5E with academic ability was found towards science process skills.
\end{abstract}

Keywords: Problem Based Learning Model (PBM), Student Activity Sheet (LKPD) 5E, Science Process Skills.

\section{PENDAHULUAN}

Pada abad ke 21 sistem pedidikan nasional menghadapi tantangan yang sangat komplek dalam menyiapkan kualitas Sumber Daya Manusia (SDM) yang mampu bersaing di era global. Upaya yang tepat untuk menyiapkan SDM yang berkualitas dan bermutu tinggi adalah pendidikan. Empat strategi dalam mensukseskan pendidikan menurut Commission On Education For The 21 Century dalam Said [1] yaitu: (1) learning to learn yaitu memuat bagaimana peserta didik mampu menggali informasi yang ada disekitarnya dari ledakan informasi itu sendiri, (2) learning to be yaitu peserta didik diharapkan mampu untuk mengenali dirinya sendiri serta mampu beradaptasi dengan lingkunganya, (3) learning to do yaitu kegiatan pembelajaran berupa tindakan atau aksi untuk memunculkan ide yang berkaitan dengan sainstek, (4) learning to be together yaitu bagaimana hidup dalam masyarakat yang saling bergantung antara satu dengan yang lain, sehingga mampu bersaing secara sehat dan bekerja sama serta mampu menghargai orang lain.

Peserta didik dalam pelaksanaan pembelajaran dituntut memiliki keterampilan yang dapat membantu peserta didik memahami konsepkonsep pelajaran IPA secara tuntas. Salah satu jenis keterampilan yang harus dikuasai oleh peserta didik dalam mata pelajaran IPA adalah keterampilan proses sains. Keterampilan proses 
sains (KPS) merupakan hal yang fundamental dalam proses pembelajaran IPA. KPS adalah suatu keterampilan yang mencakup tentang langkahlangkah ilmiah untuk menyelesaikan suatu permasalahan yang disajikan dalam bentuk lembar kegiatan peserta didik. Menurut Michael [2] KPS (science process skill) dapat diartikan sebagai satu set keterampilan yang dapat ditransfer dan menggambarkan kebiasaan seorang peneliti. KPS juga identik dengan permasalahan yang dapat diselesaikan melalui langkah-langkahnya. Keberhasilan atau selesainya masalah dengan baik dan benar merupakan wujud dari pelaksanaan KPS yang dilakukan dengan benar atau sesuai dengan indikator yang sudah ditentukan.

Menurut Rustaman [3] indikator KPS meliputi melakukan pengamatan (observasi), menafsirkan pengamatan (interprentasi), mengelompokkan (klasifikasi), meramalkan (prediksi), berkomunikasi, berhipotesis, merencanakan percobaan, menerapkan konsep dan mengajukan pertanyaan. Sedangkan indikator KPS yang digunakan dalam penelitian ini meliputi mengobservasi, merumuskan masalah, berhipotesis, melakukan percobaan, menerapkan konsep dan menyimpulkan.

Penerapan kurikulum 2013 menuntut peserta didik untuk terampil dalam mengerjakan maupun menyelesaikan tugas yang diberikan oleh guru, baik tugas kelompok maupun individu. Dalam pembelajaran IPA kegiatan peserta didik banyak menggunakan prosedur kerja ilmiah oleh karena itu peserta didik harus menguasai KPS dalam pembelajaran, namun kenyataannya pada proses pembelajaran saat ini guru maupun peserta didik terbiasa dengan metode-metode tradisional seperti metode ceramah dan lainya, akibat yang ditimbulkan adalah keterampilan peserta didik dalam bidang proses sains sulit untuk ditingkatkan. Rendahnya KPS yang dimiliki oleh peserta didik disebabkan oleh beberapa faktor diantaranya pembelajaran masih didominasi oleh guru, model pembelajaran yang digunakan masih bersifat monoton, fasilitas pembelajaran terbatas, minat dan motivasi rendah, dan bahan ajar yang disediakan oleh guru masih terpaku pada buku paket.

Model Pembelajaran Berbasis Masalah (PBM) yang dipadukan dengan LKPD 5E merupakan salah satu model pembelajaran inovatif yang terintegrasi untuk dapat melatih KPS peserta didik. Tahapan tahapan LKPD 5E yang meliputi engage (menumbuhkan rasa ingin tahu dengan cara mengajukan pertanyaan tentang objek atau kejadian di lingkungan), explor (merencanakan dan melakukan investigasi sederhana untuk mengumpulkan data yang relevan), explain (menggunakan data dan pengetahuan ilmiah untuk menghasilkan penjelasan, elaborate (mengembangkan strategi, konsep, prinsip dan penjelasan untuk masalah dan pertanyaan baru dan evaluate (evaluasi dan penilaian sebagai proses pengumpulan data hasil pembelajaran) disusun berdasarkan sintak model PBM yang meliputi: (1) memberikan orientasi tentang permasalahannya kepada peserta didik, (2) mengorganisasikan peserta didik untuk meneliti, (3) membantu investigasi mandiri dan kelompok, (4) mengembangkan dan mempersentasikan hasil, (5) menganalisis dan mengevaluasi proses mengatasi masalah.

Beberapa penelitian menunjukan bahwa penggunaan model PBM dan LKPD 5E sangat efektif dalam meningkatkan keterampilan proses sains peserta didik diantaranya: (1) Nurlina [4] dengan hasil penelitian menunjukan bahwa penggunan PBM dapat meningkatkan KPS peserta didik, (2) Gazali [5] dengan hasil penelitian menunjukan bahwa ada hubungan yang signifikan dan positif antara keterampilan proses sains dengan kemampuan berpikir kritis pada peserta didik yang belajar menggunakan model siklus belajar 5E. Berdasarkan uraian di atas, maka peneliti tertarik untuk melakukan penelitian tentang pengaruh pembelajaran berbasis masalah dipadukan LKPD 5E terhadap keterampilan proses sains ditinjau dari kemampuan akademik peserta didik.

\section{METODE PENELITIAN}

Penelitian ini termasuk jenis penelitian eksperimen dengan design quasi experimen yang bertujuan untuk mencari pengaruh perlakuan tertentu terhadap variabel-variabel yang diteliti. Bentuk design quasi experimen yang digunakan adalah pretest postest kontrol group design dengan rancangan faktorial $2 \times 2$. Populasi yang digunakan dalam penelitian ini adalah semua peserta didik kelas VII SMP Negeri 3 Mataram yang berjumlah 262 peserta didik. Sedangkan sampel terdiri dari 4 kelas berjumlah 114 peserta didik yang diambil dengan tehnik Purposive Sampling. Instrumen penelitian yang digunakan yakni lembar observasi keterlaksanaan RPP, berupa check list keterlaksanaan sintaks pembelajaran yang diisi oleh observer, tes keterampilan proses sains menggunakan soal uraian yang berjumlah 10 (sepuluh) soal. Analisis data diawali dengan uji normalitas dan uji homogenitas dan dilanjutkan dengan uji hipotesis menggunakan uji Anacova dengan bantuan SPSS versi 22. Untuk mengetahui peningkatan nilai rata-rata peserta didik pada saat pretest dan posttest, dilakukan analisis $\mathrm{N}$-gain terhadap keterampilan proses sains peserta didik dengan menggunakan persamaan:

$N$-gain $(\%)=\frac{\text { nilai postest-nilai pretest }}{\text { nilai maksimum-nilai pretest }} \times 100 \%$

Setelah memperoleh data nilai KBK, KPS dan PK IPA peserta didik, kemudian hasil penghitungan $N$-gain diinterpretasikan sesuai kriteria pada Tabel 1 berikut: 
Tabel 1 Kriteria Skor $N$-gain

\begin{tabular}{cc}
\hline Nilai $N$-gain $\langle g\rangle$ & Kategori Peningkatan Perolehan \\
Skor \\
\hline$\langle g\rangle>70 \%$ & Tinggi \\
$30 \%\langle\langle g\rangle \leq 70 \%$ & Sedang \\
$\langle g\rangle \leq 30 \%$ & Rendah \\
\hline
\end{tabular}

(Sumber: Hake [6]

\section{HASIL DAN PEBAHASAN}

Nilai rata-rata pretest KPS di KAT kelas eksperimen maupun kontrol lebih tinggi dari pada KAR. Nilai rata-rata pretest KPS peserta didik di KAT kelas kontrol lebih tinggi jika dibandingkan kelas eksperimen yaitu secara berurutan 73,75 $( \pm 2,7)$ dan $68,75( \pm 2,7)$ begitu juga nilai rata-rata pretest pada KAR di kelas kontrol dan kelas ekpserimen secara berurutan $60( \pm 7,1)$ dan $55( \pm 5,1)$.
Nilai rata-rata posttest $( \pm$ SD) KPS peserta didik di KAT kelas eksperimen lebih tinggi dibandingkan kelas kontrol, Sedangkan pada KAR berada pada level yang sama. Nilai rata-rata posttest KBK peserta didik di kelas eksperimen pada KAT dan KAR secara berurutan 76,25 $( \pm 5,6)$ dan 73,75 $( \pm 4,3)$, sedangkan di kelas kontrol nilai rata-rata posttest pada KAT dan KAR secara berurutan 75 $( \pm 3,0)$ dan $62,5( \pm 6,6)$. Lihat Gambar 1 .

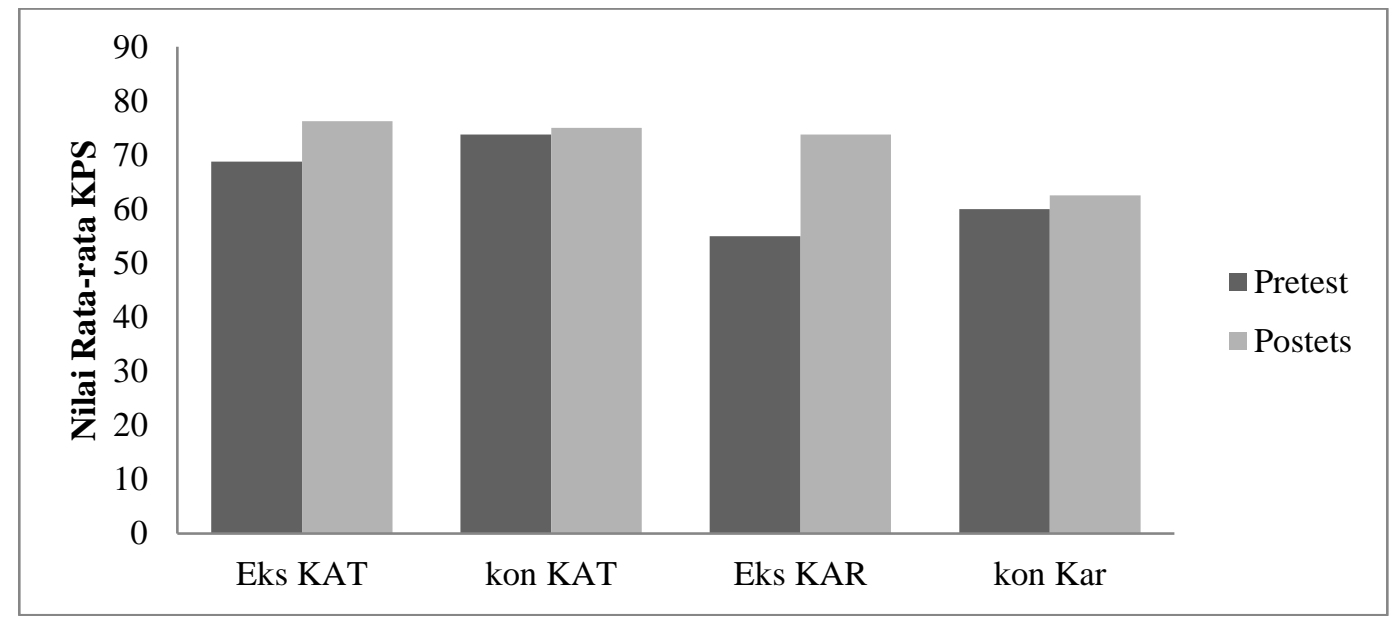

Gambar 1. Perbandingan Nilai Rata Pretest dan Posttest KBK.Batang Galat Menunjukan Nilai Rata-rata; Eks= Eksperimen; Kon=Kontrol; KAT=Kelompok Akademik Tinggi; KAR= kelompok akademik Rendah

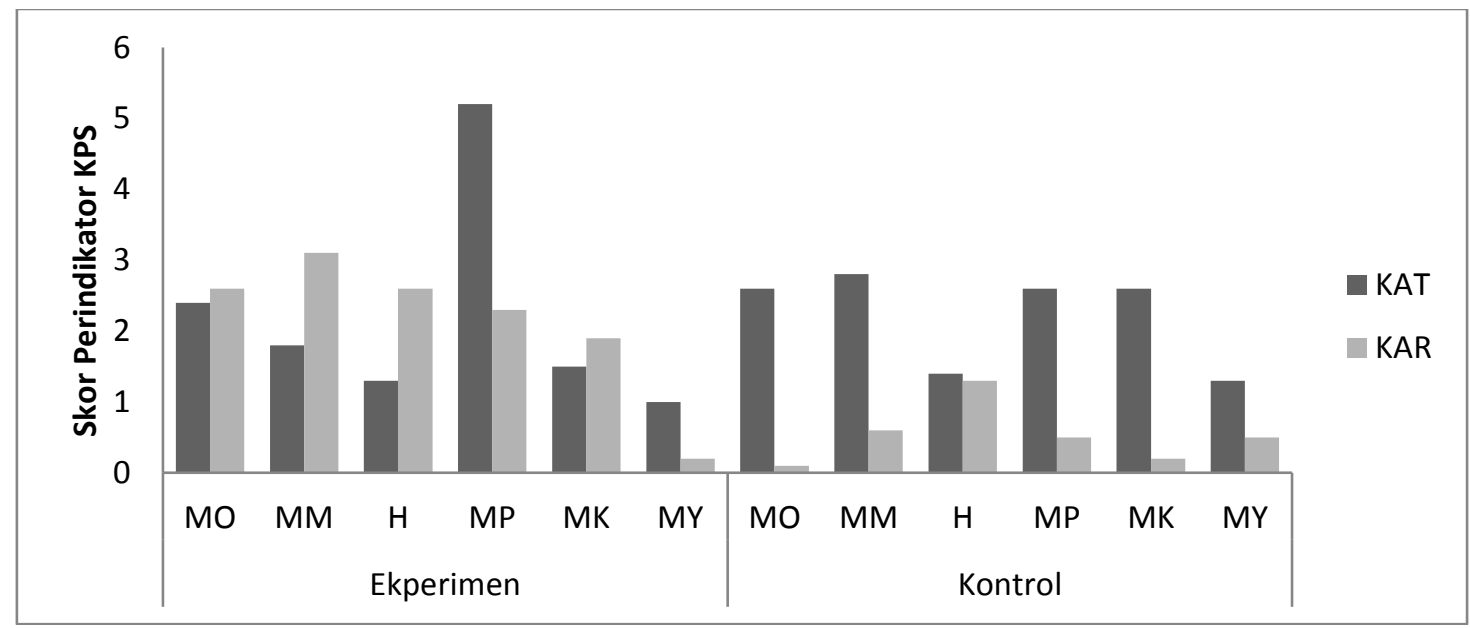

Gambar 2 Skor Perindikator KPS.

Batang Galat Menunjukan Skor Perindikator KPS; KAT=Kelompok Akademik Tinggi; KAR= Kelompok Akademik Rendah; $\mathrm{MO}=$ Melakukan Observasi; $\mathrm{MM}=$ Merumuskan Masalah; $\mathrm{H}=$ Berhipotesi; $\mathrm{MP}=\mathrm{Melakukan}$ Percobaan; MK= Menerapkan Konsep; MY= Menyimpulkan. 
Pada penelitian ini juga dilakukan pengukuran terhadap nilai perindikator KPS yaitu: mengobservasi, merumuskan masalah, berhipotesis, melakukan percobaan, menerapkan konsep dan menyimpulkan. Rata-rata nilai masing-masing indikator KPS diuji menggunakan uji $N$-gain. Berdasarkan uji $N$-gain yang sudah dilakukan menunjukan bahwa indikator KPS yang mengalami peningkatan tinggi pada indikator keempat (melakukan percobaan) di kelas eksperimen pada kemampuan akademik tinggi, sedangkan di kelas kontrol peningkatan tinggi terlihat pada indikator kedua (merumuskan masalah) pada kemampuan akademik tinggi. Skor indikator keterampilan proses sains dapat dilihat pada Gambar 2 berikut:

Perbandingan nilai rata-rata N-gain KPS peserta didik menunjukan bahwa $\mathrm{N}$-gain di KAR kelas eksperimen jauh lebih tinggi dibandingkan kelas kontrol, begitu juga nilai N-gain KAT di kedua kelas tersebut (Gambar 3). Hasil ini berarti N-gain lebih tinggi KAR dari pada KAT baik di kelas eksperimen maupun Kontrol. Di kelas eksperimen pada KAT dan KAR mempunyai Ngain dengan ratarata nilai secara berurutan $25(14,4)$ dan 47,5 (60), sedangkan di kelas kontrol mempunyai $\mathrm{N}$-gain dengan rata-rata secara berurutan $10(8,3)$ dan 7,5 $(5,1)$.

Rata-rata KPS peserta didik sebelum diberikan perlakuan pada KAT di kelas eksperimen
68,4 \% dalam kategori baik dan 31,5\% kategori kurang, sedangkan pada kelas kontrol $100 \%$ dalam kategori baik. Setelah diberikan perlakuan KPS peserta didik mengalami peningkatan lebih besar yaitu pada kelas eksperimen $47,3 \%$ berada dalam kategori sangat baik dan 52,6\% dalam kategori baik sedangkan pada kelas kontrol $31,5 \%$ berada dalam kategori sangat baik dan $68,4 \%$ berada dalam kategori baik. Hal tersebut menunjukan peningkatan KPS lebih tinggi di kelas ksperimen jika di bandingkan kelas kontrol.

Kelompok akademik rendah (KAR) pada kelas eksperimen sebelum diberikan perlakuan menunjukan 26,3\% dalam kategori cukup dan $73,6 \%$ berada dalam kategori kurang sedangkan pada kelas kontrol $21 \%$ dalam kategori baik, $36,8 \%$ dalam kategori cukup dan $42,1 \%$ berada dalam kategori kurang. Setelah diberikan perlakuan peningkatan yang besar terjadi pada kelas ekperimen yaitu 26,3\% dalam kategori sangat baik dan $73,6 \%$ berada dalam kategori baik sedangkan pada kelas kontrol 26,3\% dalam kategori baik, $57,8 \%$ dalam kategori cukup dan $15,7 \%$ dalam kategori kurang. Hal tersebut menunjukan peningkatan KPS pada kelas eksperimen sangat signifikan jika dibandingkan dengan kelas control, dapat dilihat pada Gambar 2 berikut:

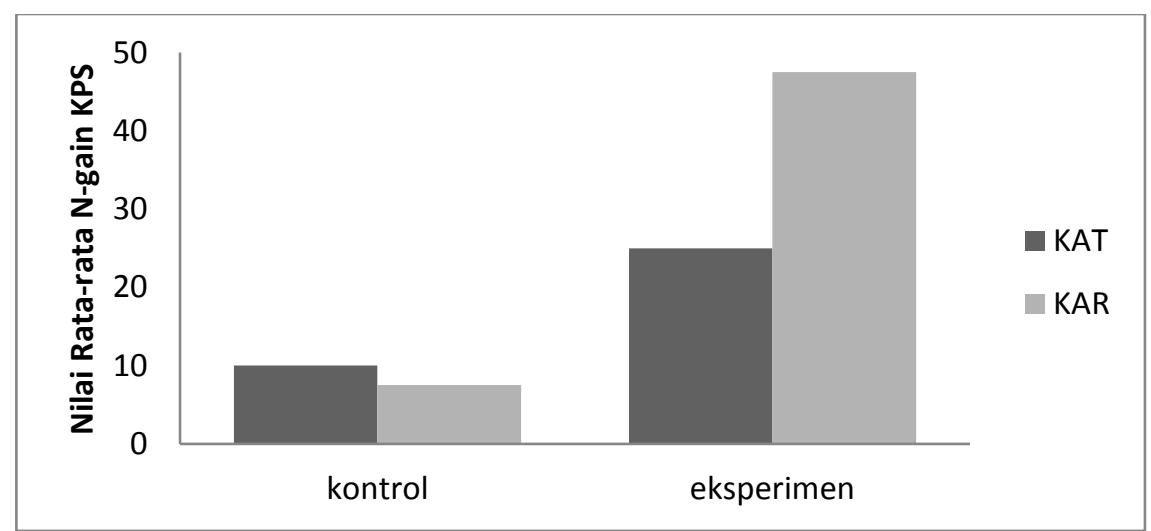

Gambar 2. Perbandingan Nilai Rata-Rata N gain KPS. Batang Galat Menunjukan KAT= Kemampuan Akademik Tinggi, KAR= Kemampuan Akademik Rendah.

\section{Pengaruh model pembelajaran berbasis masalah dipadukan LKPD 5E terhadap keterampilan proses sains}

Hasil uji hipotesis terhadap keterampilan proses sains peserta didik menunjukkan bahwa, model PBM dipadukan LKPD 5E berpengaruh terhadap keterampilan proses sains peserta didik $(\mathrm{F}=$ 80,43; df $=1 ; \mathrm{p}<0,05)$. Hasil penelitian ini sejalan dengan penelitian yang dilakukan Fitriyani [7], Hartati [8], Yew [9] dan Apriani [10].

Terjadinya peningkatan keterampilan proses sains dalam penelitian ini karena pada dasarnya PBM merupakan model pembelajaran yang menjadikan peserta didik sebagai pelaku utama dalam proses pembelajaran (student center) sehingga peserta didik merasa tertantang untuk aktif berpartisipasi dalam pembelajaran baik dalam memecahkan masalah, mencari solusi, memahami dan menerapkan konsep-konsep IPA yang dimiliki. Selain itu PBM juga merupakan model pembelajaran yang dapat membangkitkan motivasi peserta didik sehingga dapat menumbuhkan rasa ingin tahu yang tinggi tentang masalah-masalah yang disajikan dalam proses pembelajaran maupun masalah yang ada dalam kehidupan sehari-hari. 
Temuan dalam penelitian ini dipertegas oleh hasil penelitian yang dilakukan oleh Harun [11] dan Gayatri [12].

Penggunaan LKPD 5E yang teritegrasi dengan model PBM juga merupakan penyebab terjadinya peningkatan keterampilan proses sains karena LKPD 5E merupakan LKPD yang disusun berdasarkan tahapan-tahapan yang dapat memfasilitasi peserta didik secara aktif dalam menciptakan pengetahuan baru untuk mengembangkan struktur kognitif yang dimiliki, mampu menjelaskan konsep yang telah diperoleh dan dapat merangsang rasa ingin tahu peserta didik. Temuan dalam penelitian ini dipertegas oleh hasil penelitian yang dilakukan oleh Ergin [13].

\section{Pengaruh kemampuan akademik terhadap keterampilan proses sains}

Kemampuan akademik berpengaruh terhadap keterampilan proses sains peserta didik $(\mathrm{F}=$ 159,769; df $=1 ; p<0,05)$. Hasil penelitian ini sejalan dengan penelitian yang dilakukan Susilawati [14] yang menyatakan bahwa kemampuan akademik berpengaruh signifikan terhadap kemampuan berpikir kritis peserta didik dan Mamu [15] menyatakan bahwa kemampuan akademik berpengaruh signifikan terhadap kemampuan berpikir kritis dan hasil belajar kognitif peserta didik.

Hasil penelitian ini menunjukan bahwa nilai rata-rata $\mathrm{N}$-gain pada kelas eksperimen jauh lebih tinggi pada peserta didik berkemampuan rendah (KAR) dari pada peserta didik berkemampuan tinggi (KAT) sedangkan pada kelas kontrol nilai rata-rata peserta didik berkemampuan rendah (KAR) lebih rendah jika dibandingkan peserta didik berkemampuan tinggi (KAT) namun perbedaan ini hanya sedikit yaitu $2.5 \%$.

Hasil penelitian ini sejalan dengan penelitian yang dilakukan oleh Hartati [8] yang menyatakan bahwa peserta didik berkemampuan akademik rendah akan lebih baik jika diajarkan dengan model pembelajaran siklus belajar 5E karena telah terbukti mampu mensejajarkan keterampilan proses sains dan hasil belajar kognitif dengan siswa berkemampuan akademik tinggi.

Proses kerjasama antar anggota kelompok dalam setiap tahapan model PBM yang dipadukan LKPD 5E terjadi dengan sangat baik. Hal tersebut ditunjukkan peserta didik yang memiliki kemampuan akademik tinggi membimbing peserta didik yang memiliki kemampuan akademik rendah sehingga hasil keterampilan proses sains peserta didik berkemampuan akademik rendah dapat menyamai hasil dari peserta didik berkemampuan akademik tinggi.

\section{Interaksi model pembelajaran berbasis masalah dipadukan LKPD $5 \mathrm{E}$ dengan kemampuan akademik terhadap keterampilan proses sains}

Interaksi model pembelajaran berbasis masalah (PBM) dipadukan LKPD 5E dengan kemampuan akademik berpengaruh terhadap kemampuan keterampilan peserta didik $(\mathrm{F}=34,489$; df $=1 ; p<0,05)$. Hasil ini memberikan makna bahwa model pembelajaran berbasis masalah (PBM) yang dipadukan LKPD 5E dapat diterapkan baik pada peserta didik berkemampuan akademik tinggi maupun peserta didik berkemampuan akademik rendah.

Adanya interaksi antara model PBM yang dipadukan LKPD 5E dengan kemampuan akademik terhadap KPS peserta didik terjadi karena penerapan model PBM yang dipadukan LKPD 5E dapat membantu guru dalam proses transefer ilmu pengetahuan dengan cara yang terstruktur dan menyenangkan serta mudah dipahami oleh peserta didik Hal tersebut sejaln dengan penelitian yang dilakukan oleh Ghorgiu [16] yang menyatakan bahwa penggunaan model pbm dalam pembelajaran dapat membagun hubungan positip antara peserta didik denga guru.

Hasil penelitian ini sejalan dengan hasil penelitian yan dilakukan oleh Gazali [5] ada interaksi antara keterampilan proses sains dengan kemampuan berpikir kritis pada siswa yang belajar menggunakan model siklus belajar 5E dan Laila [17] ada pengaruh interaksi strategi pembelajaran Cooperative Script dan kemampuan akademik terhadap kemampuan berpikir kritis dan pemahaman konsep siswa.

Penggunaan model PBM dipadukan LKPD 5E supanya memperhatikan beberapa hal diantaranya: (1) Menyesuaikan materi dengan sintak model PBM yang dipadukan LKPD 5E; (2) Menyediakan sarana dan prasarana yang di butuhkan dalam proses pembelajaran; (3) Memenejmen waktu dengan sebaik-baiknya; (4) Memperhatiakan pengalaman belajar peserta didik; (4) Guru perlu lebih banyak berlatih dalam menggunakan model PBM yang dipadukan LKPD 5E; (5) Guru perlu mengumpulakan lebih banyak refrensi, mengikuti pelatihan-pelatihan yang terkait dengan model-model pembelajaran inovatif; (6) Guru sebaiknya membagi kelompok peserta didik secara heterogen, sehingga hasil belajar kognitif peserta didik di kelompok akademik rendah mampu menyamakan hasil belajar di kelompok akademik tinggi.

\section{KESIMPULAN}

Berdasarkan hasil penelitian yang sudah dilakukan dapat disimpulkan bahwa, terdapat pengaruh model pembelajaran berbasis masalah dipadukan LKPD 5E dan pengaruh kemampuan akademik terhadap terhadap keterampilan proses 
sains peserta didik dan pengaruh interaksi kedua faktor terbukti.

\section{DAFTAR PUSTAKA}

[1]. Said, N. A., Hustim, R., Nurlina. 2014. Peranan Model Pembelajaran Berbasis Masalah Terhadap Keterampilan Proses Sains Peserta Didik Kelas VIII SMP Negeri 1 Tellu- Limpoe Kabupaten Sindenreng Rappang. Pendidikan fisika FKIP Universitas Muhammadiyah Makassar 2 (3): 226-232.

[2]. Michael, J., James, P. R., Okey, F., Dilashaw, G. 1983. The Relationship Between Science Process Skill and Formal Thingking Abilities. Journal of Research in Science Teaching 20 (3): 239-246.

[3]. Rustaman, N., Dirdjosoemarto, S., Yudianto, S. A., Achmad, Y., Subekti, R., Rochintawati, D., Nujhani, M. 2005. Strategi Belajar Mengajar Biologi. Malang. UM press.

[4]. Nurlina. 2015. Peningkatan Keterampilan Proses Sains Dengan Menerapkan Model Pembelajaran Berdasarkan Masalah Pada Peserta Didik Kelas VIIIB SMPN 1 Lappariaja Kabupaten Bone. Jurnal Pendidikan Fisika Universitas Muhammadiyah Makassar 3 (1): 14-20.

[5]. Gazali, A., Hidayat A., Yuliati L. 2015. Efektivitas Model Siklus Belajar 5E Terhadap Keterampilan Proses Sains dan Kemampuan Berpikir Kritis Siswa: Jurnal Pendidikan Sains 3 (1): 10- 16.

[6]. Hake, R. 1999. Analyzing Change/Gain Score. Indiana: Indiana university.

[7]. Fitriyani, R., Corebima, A. D., Ibrohim. 2015. Pengaruh Strategi Pembelajaran Problem Based Learning dan Inkuiri Terbimbing Terhadap Keterampilan Metakognitif, Berpikir Kritis, dan Hasil Belajar Kognitif Siswa SMA: Jurnal Pendidikan Sains 3 (4): 186-200.

[8]. Hartati, T. A. W., Corebima A. D., Suwono H. 2015. Pengaruh Model Pembelajaran Inkuiri Terstruktur dan Siklus Belajar 5E terhadap Keterampilan Proses Sains dan Hasil Belajar Kognitif Siswa pada Kemampuan Akademik Berbeda: Jurnal Pendidikan Sains 3 (1): 22-30.

[9]. Yew, E. H. J., Goh, K. 2016. Problem Based Learning: An Overview of Its Process and Impact on Learning: Health Professions Education 2 (0): 27-79.
[10]. Apriani, N., Ayub, S., Hikmawati. 2016. Pengaruh Model Pembelajaran Berbasis Masalah Terhadap Hasil Belajar Fisika Siswa Kelas X SMAN 2 Praya Tahun Pelajaran 2015/2016. J. Pijar MIPA 11( 2): 125-130.

[11]. Haruna, N. F., Yusofb, K. M., Jamaludin, M. Z., Hassand, S. H. A. S. 2012. Motivation in Problem based Learning Implementation: Procedia - Social and Behavioral Sciences 56 (0): $233-242$.

[12]. Gayatri, I. G. A. S., Jekti, D. S. D., \& Jufri, A. W. (2013). Efektifitas Pembelajaran Berbasis Masalah (PBM) Dan Strategi Kooperatif Terhadap Kemampuan Menyelesaikan Masalah Dan Hasil Belajar Kognitif Biologi Ditinjau Dari Kemampuan Akademik Awal Siswa Kelas X SMA Negeri 3 Mataram. J. Pijar MIPA, 8(2): 41-46.

[13]. Ergin, I., Kanli, U., Unsal, Y. 2008. An Example for the Effect of 5E Model on the Academic Success and Attitude Levels of Students: Inclined Projectile Motion. Turkish: Journal of Turkish Science Education 5(3): 47-59.

[14]. Susilawati., Jamaluddin., Bachtiar, B. 2017. Pengaruh Model Pembelajaran Berbasis Masalah (PBM) Berbantuan Multimedia Terhadap Kemampuan Berpikir Kritis Peserta Didik Kelas VII SMP Negeri 2 Mataram Ditinjau Dari Kemampuan Akademik: J. Pijar MIPA 12 (2): 64-70.

[15]. Mamu, H. D. 2014. Pengaruh Strategi Pembelajaran, Kemampuan Akademik dan Interaksinya Terhadap Keterampilan Berpikir Kritis dan Hasil Belajar Kognitif IPA Biologi. Jurnal Pendidikan Sains 2 (1): $1-11$.

[16]. Gorghiua, G., Drăghicescub, L. M., Cristeac M., Petrescub A M., Gorghiud L M. 2015. Problem-Based Learning - An Efficient Learning Strategy In The Science Lessons Context: Procedia - Social and Behavioral Sciences 19 (1):1865 - 1870.

[17]. Laila S., Corebima, A. D., Abdul, G. 2015. Pengaruh Strategi Pembelajaran Cooperative Script dan Kemampuan Akademik Siswa Terhadap Kemampuan Berpikir Kritis dan Pemahaman Konsep Biologi Kelas XI SMA Di Kabupaten Maluku Tengah: Jurnal Biology Science \& Education 4(2): 47-57. 